\title{
Study of Viral Load and CD4 Count in Diagnosis of HIV-1 Positive Patients
}

Kumar $\mathbf{M}^{1 *}$, Kumar $\mathbf{R}^{2}$, Mahdi $\mathbf{A A}^{3}$ and Dhole $\mathbf{T N}^{1}$ ${ }^{1}$ Department of Microbiology, Sanjay Gandhi Post Graduate Institute of Medical Sciences, Uttar Pradesh, India

${ }^{2}$ Department of Life Sciences, Chhatrapati Shahu Ji

Maharaj University, Uttar Pradesh, India

${ }^{3}$ Department of Biochemistry, King George's Medical University, Uttar Pradesh, India

*Corresponding author: Manoj Kumar, Department of Microbiology, Sanjay Gandhi Post Graduate Institute of Medical Sciences, Lucknow, Uttar Pradesh 226014, India

Received: April 10, 2017; Accepted: May 05, 2017; Published: May 12, 2017

\begin{abstract}
This study reports the distribution of CD4 counts and viral loads in first-time HIV positive patients.

One hundred cases of different kinds of HIVIAIDS were included in this study. Written consent was obtained from each participant for their information to be stored in the clinic database and used for research purposes. Blood samples were collected from these volunteers in the sterilized vials and processed for CD4 count and viral load.Data were analyzed with statistical package (SPSS 16.0) software and correlation coefficients and correlation matrix were determined.

One hundred cases (37 males and 63 females) of different kinds of HIVI AIDS were included in this study with a mean age ranged from $33.45 \pm 13.052$. Half of the patients below 29 years of age and only $4 \%$ are above 59 years of age. Relationship between the CD4 cell count and the dependent variable viral load. $\mathrm{R}$, the multiple correlation coefficients, is the linear correlation between the observed and predicted values of the dependent variable viral load. Its large value indicates a strong relationship between CD4 cell count values and viral load $(R=0.837)$. If $R$ value is small, then it takes large errors. For $R$ square 0.701 , nearly one third the variation in viral load is explained by the independent variable CD4 cell count. The Gender wise mean comparison of viral load in CD4 positive patients was found significant $(p<0.05)$.
\end{abstract}

HIV-infected men at their first HIV diagnosis are more likely to have lower CD4 counts and higher viral loads than women.

Keywords: CD4 Count; Viral Load; HIV Patients; Diagnosis; Gender

\section{Introduction}

HIV RNA (viral load) and CD4 T lymphocyte (CD4) cell count are the two surrogate markers of antiretroviral treatment (ART) responses and HIV disease progression that have been used for decades to manage and monitor HIV infection. Viral load is the most important indicator of initial and sustained response to ART (AI) and should be measured in all HIV-infected patients at entry into care (AIII), at initiation of therapy (AIII), and on a regular basis thereafter.

Viral load is a marker of response to ART. A patient's pre-ART viral load level and the magnitude of viral load decline after initiation of ART provide prognostic information about the probability of disease progression [1]. The key goal of ART is to achieve and maintain durable viral suppression. Thus, the most important use of the viral load is to monitor the effectiveness of therapy after initiation of ART [2].

Measurement of CD4 count is particularly useful before initiation of ART. The CD4 cell count provides information on the overall immune function of an HIV-infected patient $[3,4]$. The measurement is critical in establishing thresholds for the initiation and discontinuation of opportunistic infection (OI) prophylaxis and in assessing the urgency to initiate ART.

This study reports the distribution of CD4 counts and viral loads in first-time HIV positive patients.

\section{Materials and Methods}

One hundred cases of different kinds of HIV/AIDS were included in this study. Written consent was obtained from each participant for their information to be stored in the clinic database and used for research purposes. Their age ranged between 18-60 years. All these subjects were selected from Sanjay Gandhi Post Graduate Institute of Medical Sciences, Lucknow, India. Blood samples were collected from these volunteers in the sterilized vials and processed for CD4 count and viral load. Viral Load testing was conducted using the Nuclisens Nucleic Acid Sequence Based Amplification (NASBA, bioMerieux,

Table 1: Distribution of age at different intervals with CD4 positivity in Case group.

\begin{tabular}{|c|c|c|c|c|}
\hline \multirow{2}{*}{ Age } & \multicolumn{4}{|c|}{ Cases (N=100) } \\
\cline { 2 - 5 } & \multicolumn{2}{|c|}{ CD4 +ve (n=73) } & \multicolumn{2}{c|}{ CD4 -ve (27) } \\
\cline { 2 - 5 } & $\mathrm{N}$ & $\%$ & $\mathrm{~N}$ & $\%$ \\
\hline Less than 29 & 32 & 43.84 & 7 & 25.93 \\
\hline between 29 to 39 & 16 & 21.92 & 9 & 33.33 \\
\hline between 40 to 49 & 11 & 15.07 & 3 & 11.11 \\
\hline between 50 to 59 & 11 & 15.07 & 7 & 25.93 \\
\hline Above 59 & 3 & 4.11 & 1 & 3.70 \\
\hline
\end{tabular}

Applied $\mathrm{X} 2$ test for significance. $\mathrm{P}$ value $=0.413$.
J Fam Med - Volume 4 Issue 4 - 2017

ISSN : 2380-0658 | www.austinpublishing group.com

Kumar et al. (C) All rights are reserved
Citation: Kumar M, Kumar R, Mahdi AA and Dhole TN. Study of Viral Load and CD4 Count in Diagnosis of HIV-1 Positive Patients. J Fam Med. 2017; 4(4): 1117. 
Table 2: Gender distribution in CD4 positivity in Case group.

\begin{tabular}{|c|c|c|c|c|}
\hline \multirow{2}{*}{ Gender } & \multicolumn{4}{|c|}{ Cases (N=100) } \\
\cline { 2 - 5 } & \multicolumn{2}{|c|}{ CD4 +ve (n=73) } & \multicolumn{2}{c|}{ CD4 -ve (27) } \\
\cline { 2 - 5 } & $\mathrm{N}$ & $\%$ & $\mathrm{~N}$ & $\%$ \\
\hline Male & 30 & 41.10 & 12 & 44.44 \\
\hline Female & 43 & 58.90 & 15 & 55.56 \\
\hline
\end{tabular}

Applied $\mathrm{X} 2$ test for significance. P-value $=0.042^{*}$; ${ }^{*}$ Significant.

Table 3: Gender distribution with CD4 cell count groups of CD4 positive patients in Case group.

\begin{tabular}{|c|c|c|c|c|c|c|}
\hline \multirow{3}{*}{ Gender } & \multicolumn{5}{|c|}{ Cases (N=100) } \\
\cline { 2 - 7 } & \multicolumn{5}{|c|}{ CD4 +ve (n=73) } \\
\cline { 2 - 7 } & Less than 200 & \multicolumn{2}{|c|}{ between 200 to 500 } & Greater than 500 \\
\cline { 2 - 7 } & $\mathrm{N}$ & $\%$ & $\mathrm{~N}$ & $\%$ & $\mathrm{~N}$ & $\%$ \\
\hline \multirow{2}{*}{ Male } & 8 & 40 & 16 & 45.71 & 6 & 33.33 \\
\hline Female & 12 & 60 & 19 & 54.29 & 12 & 66.67 \\
\hline
\end{tabular}

Applied $\mathrm{X} 2$ test for significance. $\mathrm{P}$-value $=0.682$.

Table 4: Frequency distribution of gender and age intervals according to CD4 positive patients.

\begin{tabular}{|c|c|c|c|c|c|c|}
\hline \multirow{2}{*}{ Gender } & \multirow{2}{*}{ Age Category } & \multicolumn{2}{|c|}{ CD4 +ve $(n=73)$} & \multicolumn{2}{|c|}{$\begin{array}{c}\text { CD4 -ve } \\
(\mathrm{n}=27)\end{array}$} & \multirow{2}{*}{$\mathrm{p}$-value } \\
\hline & & $\mathrm{N}$ & $\%$ & $\mathrm{~N}$ & $\%$ & \\
\hline \multirow{5}{*}{ Male } & Less than 29 & 14 & 19.18 & 5 & 18.52 & \multirow{5}{*}{0.071} \\
\hline & between 29 to 39 & 12 & 16.44 & 3 & 11.11 & \\
\hline & between 40 to 49 & 4 & 5.48 & 2 & 7.41 & \\
\hline & between 50 to 59 & 0 & 0.00 & 2 & 7.41 & \\
\hline & Above 59 & 0 & 0.00 & 0 & 0.00 & \\
\hline \multirow{5}{*}{ Female } & Less than 29 & 18 & 24.66 & 3 & 11.11 & \multirow{5}{*}{0.380} \\
\hline & between 29 to 39 & 4 & 5.48 & 5 & 18.52 & \\
\hline & between 40 to 49 & 7 & 9.59 & 1 & 3.70 & \\
\hline & between 50 to 59 & 11 & 15.07 & 5 & 18.52 & \\
\hline & Above 59 & 3 & 4.11 & 1 & 3.70 & \\
\hline
\end{tabular}

Applied $\mathrm{X} 2$ test for significance.

Inc. Durham, NC) test platform for most tests (the detection limit for HIV viral load was $<400$ copies/ml) and the Real Time HIV1 Amplification Polymerase Chain reaction (PCR) (ABBOTT Molecular, Inc, Des Plaines, IL) platform in a few instances. CD4 cells were enumerated using the flow cytometry method.

Data were analyzed with statistical package (SPSS 16.0) softwareand correlation coefficients and correlation matrix were determined.Results were presented in simple tables with frequencies and percentages while statistical significance was taken to be $\mathrm{p}$ value $\leq 0.05$.

\section{Results}

One hundred cases ( 37 males and 63 females) of different kinds of HIV/AIDS were included in this study with a mean age ranged from $33.45 \pm 13.052$. Half of the patients below 29 years of age and only $4 \%$ are above 59 years of age.

Frequency distribution of Age intervals according to CD4 positivity in case groups are summarized in Table 1 . Statistically, this percentage difference among groups was not significant $(\mathrm{p}>0.05)$.
Table 5: Linear Correlation of viral load and CD4 cell count values in CD4 positive patients of treatment group $(n=73)$.

\begin{tabular}{|c|c|c|c|}
\hline R & R Square & Adjusted R Square & $\begin{array}{c}\text { Std. Error of the } \\
\text { Estimate }\end{array}$ \\
\hline 0.837 & 0.701 & 0.697 & 16495.586 \\
\hline
\end{tabular}

Table 6: Mean comparison of viral load distribution according to Gender in CD4 positive patients in treatment group $(n=73)$.

\begin{tabular}{|l|c|c|c|c|c|}
\hline \multirow{2}{*}{} & \multicolumn{2}{|c|}{ Male } & \multicolumn{2}{c|}{ Female } & \multirow{2}{*}{ p-value } \\
\cline { 2 - 5 } & Mean & SD & Mean & SD & \\
\hline Viral load & 50103.10 & 30111.83 & 63297.47 & 36133.31 & $0.032^{*}$ \\
\hline
\end{tabular}

Applied unpaired t test for significance. * Significant.

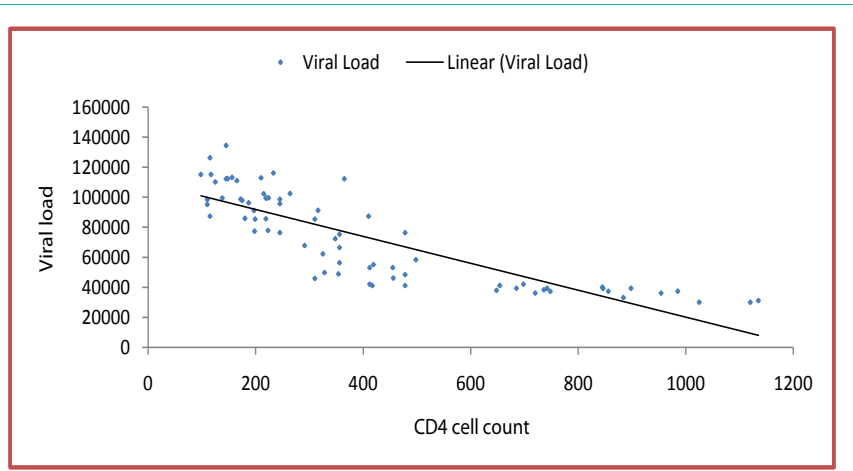

Figure 1: Viral load is inversely proportional to CD4 cell count.

Frequency distribution of Gender according to CD4 positivity in cases group is summarized in Table 2. Statistically, this percentage difference among groups was significant $(\mathrm{p}<0.05)$.

Frequency distribution of Gender according to CD4 positive patients according to CD4 cell count categories in cases group are summarized in Table 3. Statistically, this percentage difference among groups was not significant ( $\mathrm{p}>0.05)$.

Frequency distribution of Gender with age category according to CD4 positive patients in cases group are summarized in Table 4. Statistically, this percentage difference among groups was not significant $(\mathrm{p}>0.05)$.

The above Table 5 reports the strength of the relationship between the $\mathrm{CD} 4$ cell count and the dependent variable viral load. $\mathrm{R}$, the multiple correlation coefficients, is the linear correlation between the observed and predicted values of the dependent variable viral load. Its large value indicates a strong relationship between CD4 cell count values and Viral load ( $\mathrm{R}=0.837)$. If $\mathrm{R}$ value is small, then it takes large errors. For R square 0.701 , nearly one third the variation in viral load is explained by the independent variable CD 4 cell count.

The ANOVA table reports a significant $F$ statistic $(F$ value $=166.71$; $P$ value $=<0.001)$ consider extremely significant.

Figure 1 shows that the viral load is inversely proportional to CD4 cell count.

The Gender wise mean comparison of viral load in CD4 positive patients of treatment group are summarized in Table 6. Statistically, this difference between males and females was found significant $(\mathrm{p}<0.05)$. 


\section{Discussion}

According to experimental work, major probability regarding occurrence of disease is more in age of below 29 years which is further elevated that male is more sensitive rather that female due to their physiological activities whereas in case of female specially under immature condition, chance for infection of HIV is more due to favorable structural designing of the female reproductive organs.

The strength of the relationship between the CD4 cell count and the dependent variable viral load. $\mathrm{R}$, the multiple correlation coefficients, is the linear correlation between the observed and predicted values of the dependent variable viral load. Its large value indicates a strong relationship between CD4 cell count values and Viral load ( $\mathrm{R}=0.837)$. If $\mathrm{R}$ value is small, then it takes large errors. For $\mathrm{R}$ square 0.701 , nearly one third the variation in viral load is explained by the independent variable cd 4 cell count similar to other studies [58]. The viral load is inversely proportional to CD4 cell count $[9,10]$.

The Gender wise mean comparison of viral load in CD4 positive patients of treatment group, statistically, this difference was found significant $(\mathrm{p}<0.05)$. Other studies have noted gender differences in viral loads and $\mathrm{CD} 4$ at various stages of the disease, where females develop AIDS at higher CD4 counts and lower viral loads [6-8].

\section{References}

1. Murray JS, Elashoff MR, lacono-Connors LC, Cvetkovich TA, Struble KA. The use of plasma HIV RNA as a study endpoint in efficacy trials of antiretroviral drugs. AIDS. 1999; 13: 797-804.

2. Plasma HIV-1 RNA (Viral Load) and CD4 Count Monitoring
3. Mellors JW, Munoz A, Giorgi JV, et al. Plasma viral load and CD4+ lymphocytes as prognostic markers of HIV-1 infection. Ann Intern Med. 1997; 126: 946-954.

4. Egger M, May M, Chene G, et al. Prognosis of HIV-1-infected patients starting highly active antiretroviral therapy: a collaborative analysis of prospective studies. Lancet. 2002; 360: 119-129.

5. Farzadegan $\mathrm{H}$, Hoover DR, Astemborski J, Lyles CM, Margolick JB, et al. Sex differences in HIV-1 viral load and progression to AIDS. Lancet. 1998; 352: 1510-1514.

6. Prins M. Do gender differences in CD4 cell counts matter? AIDS. 1999; 13 2361-2364.

7. Sterling TR, Vlahov D, Astemborski J, Hoover DR, Margolick JB, et al. Initia plasma HIV-1 RNA levels and progression to AIDS in women and men. N Engl J Med. 2001; 344: 720-725.

8. Touloumi G, Pantazis N, Babiker AG, Walker SA, Katsarou O, et al Differences in HIV RNA levels before the initiation of antiretroviral therapy among 1864 individuals with known HIV-1 seroconversion dates. AIDS. 2004; 18: $1697-1705$.

9. Cohen MS, Chen YQ, McCauley M, Gamble T, Hosseinipour MC, et al. Prevention of HIV-1 infection with early antiretroviral therapy. N Engl J Med. 2011; 365: 493-505.

10. de Wolf F, Spijkerman I, Schellekens PT, Langendam M, Kuiken C, et al AIDS prognosis based on HIV-1 RNA, CD4+ T-cell count and function: markers with reciprocal predictive value over time after seroconversion. AIDS. 1997; 11: 1799-1806.
J Fam Med - Volume 4 Issue 4 - 2017

ISSN : 2380-0658 | www.austinpublishinggroup.com

Kumar et al. (C) All rights are reserved
Citation: Kumar M, Kumar R, Mahdi AA and Dhole TN. Study of Viral Load and CD4 Count in Diagnosis of HIV-1 Positive Patients. J Fam Med. 2017; 4(4): 1117. 